\title{
ETHNIC LOADING OF FOOD AS A SUSTAINABLE CULTURE COMPONENT IN THE FORM OF PHYSICAL-GEOGRAPHICAL, SOIL AND ETHNOGRAPHIC ZONING OF THE RIGHT-BANK POLISSIA
}

\author{
Inna NESTERCHUK \\ Zhytomyr National Agroecological University, Faculty of Economics and Management \\ Department of Tourism, Old Boulevard Street, 7, 10008, Zhytomyr, Ukraine, e-mail: nester_geoek@ukr.net \\ Anna OSIPCHUK* \\ Zhytomyr National Agroecological University, Faculty of Economics and Management \\ Department of Tourism, Old Boulevard Street, 7, 10008, Zhytomyr, Ukraine, e-mail: annaosipchuck@ukr.net
}

\section{Taisia CHERNYSHOVA}

Zhytomyr National Agroecological University, Faculty of Economics and Management Department of Tourism, Old Boulevard Street, 7, 10008, Zhytomyr, Ukraine, e-mail: taisiya_1983@ukr.net

\section{Bogdan SHEVCHUK}

Zhytomyr National Agroecological University, Faculty of Economics and Management Department of Tourism, Old Boulevard Street, 7, 10008, Zhytomyr, Ukraine, e-mail: bogdan0005@gmail.com

\section{Eduard BONDARENKO}

Taras Shevchenko National University of Kyiv, Department of Geodesy and Cartography, ave. Academician Glushkov, 2, Kyiv, Ukraine, e-mail: edw@univ.kiev.ua

\begin{abstract}
Citation: Nesterchuk, I., Osipchuk, A., Chernyshova, T., Shevchuk, B., \& Bondarenko, E. (2020). ETHNIC LOADING OF FOOD AS A SUSTAINABLE CULTURE COMPONENT IN THE FORM OF PHYSICAL-GEOGRAPHICAL, SOIL AND ETHNOGRAPHIC ZONING OF THE RIGHT-BANK POLISSIA. GeoJournal of Tourism and Geosites, 30(2 supplement), 788-793. https://doi.org/10.30892/gtg.302spl02-506
\end{abstract}

\begin{abstract}
The article deals with the study of food as a sustainable component of culture and the manifestation of certain physical, geo graphical, soil and ethnographic conditions of the Right-Bank Polissia region through the prism of gastronomic tourism. Based on the analysis of analytical works of topographic and statistical content, as well as fiction that are accumulative in nature and based on factual material needed for its generalization about the gastronomy of the region, an information base has been created for further mapping by units of physical and geographical zoning. The authors develop a map of gastronomic tourism of the Right-Bank Polissia applying the methods of geoinformation analysis implemented in the environment of geoinformation systems.
\end{abstract}

Key words: Right-Bank Polissia, food, sustainable component of culture, gastronomic tourism, physical-geographical zoning, soil zoning, ethnographic zoning, gastronomic map

\section{INTRODUCTION}

The nation standard of living always depends on the development of gastronomic preferences, which are not a means of satisfying biological needs, but a manifestation of social relations inherent in sustainable food traditions, which are based on the peculiarities of economic life, and also depend on the physical and geographical conditions of the territory. The Ukrainian ethnic group has always had strong cultural contacts, which are the demonstration of hospitality and tolerance in dealing with different peoples.

\section{FORMULATION OF A SCIENTIFIC PROBLEM}

Despite the considerable study of the Right-Bank Polissia territory, it has not been considered in the symbiosis of physical, geographical, soil and ethnographic studies to determine the level of development of gastronomic tourism and to further development of the gastronomic map of the region.

\section{ANALYSIS OF RECENT RESEARCH AND PUBLICATIONS}

Culinary tourism is rising in importance as a result of the opening of a number of fine dining establishments. The growth of second homes and retirement communities also is noted as significant elements in the make-up of the Overstrand tourism economy (Rogerson and Rogerson, 2019). Traditional and everyday culture of Polissia is widely covered in the joint work of Belarusian and Ukrainian national scientists, but there is no detailed mapping of traditional forms of food and nutrition, there are also insignificant works specifically dedicated to food (Artiukh, 2018). Some experts consider the peculiarities of gastronomic tourism and the prospects for its further development in the countries or some regions, namely: the USA and Canada (LeHeup, 2015), Europe (Gheorghe et al., 2014), Slovakia (Matlovičová and Pompura, 2013), Albania (Brokaj, 2014), Suriname (Dasilva-Glasgow, 2015), Thailand (Pullphothong and Sopha, 2013), Gekchead Island, Turkey (Yurtseven, 2011). Issues of physical and geographical zoning are described in the works by Oliynyk et al., 2008; Marynych, 2005. Genetic and morphological characteristics of soils of Ukrainian Polissia, subsequent soil maps formation are studied by researchers (Tereshina and Vasilenko, 2012; Polupan, 2005). Many scientists are interested in the ethnographic zoning of Ukraine (Glushko, 2009; Makarchuk, 2012). Controversial and debatable issues of the ethnographic zoning of Ukraine are covered in the numerous works (Savchuk, 
2004; Tivodar, 2010; Ponomaryov, 1994; Pankiv, 2005; Kirchiv, 2005). The schemes of historical and ethnographic zoning of Ukraine have not yet acquired a complete form and common boundaries and need further elaboration. The conceptual apparatus needs coordination. In spite of all this, progressive steps have been taken and they require thorough generalizations of scientific values: historical and ethnographic area, historical and ethnographic region, historical and ethnographic district, ethnographic subarea. In addition, the scheme of ethnographic zoning of Ukraine is used in our scientific research (Makarchuk, 2012). This scientific work is an attempt to characterize the origin of gastronomic tourism of the Right-Bank Polissia, based on the foundations of physical, geographical, soil and ethnographic zoning.

The aim of the article is to analyze the food culture of Polishchuk-people in terms of physical, geographical, soil and ethnographic scientific research. The realization of this aim requires a number of specific tasks, in particular: to analyze the available historiography on physical, geographical, soil and ethnographic studies and their source base; to collect and systematize new bibliographic material and to introduce into scientific circulation the definitions of "gastronomic tourism", "gastronomic potential", "gastronomic destination", "gastronomic tourist", "gastronomic tourist product", to find out the peculiarities of traditional Polishchuk-people food with the subsequent creating maps of Right-Bank Polissia tourism.

\section{RESEARCH METHODOLOGY AND METHODS}

The methodological basis of this study is the basic provisions of geographical science on the interaction of society and nature, as well as geographical cartography namely the possibility of mapping complex social and natural formations with the help of cartographic models. In the course of the research, general scientific and separate scientific methods and approaches are applied, in particular: the systematic approach, the system-structural analysis and synthesis - to define the main features, concepts and principles of ethnic loading of food as a stable component of culture in the form of physical-geographical, soil and ethnographic zoning Right-Bank Polissia; the descriptive and historical comparisons - in the analysis of the main refinement of research issues; field surveys of physico-geographical, agronomic, ethnographic, the local lore - for the collection and primary systematization of factual material; informational - for comprehensive study of objects that make up the research through analysis, further systematization, reclassification of the obtained source base and for the purpose of mapping; the modeling (structural-graphic, mathematical-cartographic, cartographic) - while determining the possibilities of developing appropriate models, topics and content of maps; the generalization - for scientific substantiation and creation of derivative cartographic models on the basis of existing ones; mathematical methods - for mathematical processing of different types of information (full-scale observations, statistical, textual, etc.); cybernetic methods - for the elaboration of methods of computer processing of information, for the creation of mapping models and use of modern software products. MS Excel 2007 is used in computer systematization of material in spreadsheets; ArcGIS 10.2 geoinformation system, Adobe Photoshop raster graphics editor, Adobe Illustrator vector graphics editor are used when creating experimental map samples and developing mapping techniques.

\section{PRESENTATION OF THE BASIC MATERIAL OF THE RESEARCH}

The landscape-typological structure of the territory should be understood as the laws of the territorial structure; interconnections and relative positioning of parts of the landscape, which are relatively small natural complexes, the formation and development of which depend on the local features of each specific area (Lyubitseva, 2002). Right-Bank Polissia includes Volyn Polissia region, Zhytomyr Polissia region, Kyiv Polissia region (Nesterchuk, 2011, 2018). The designated area belongs to the Eastern European flat of the zone of mixed coniferousdeciduous forests of the Polissia region (Figure 1).

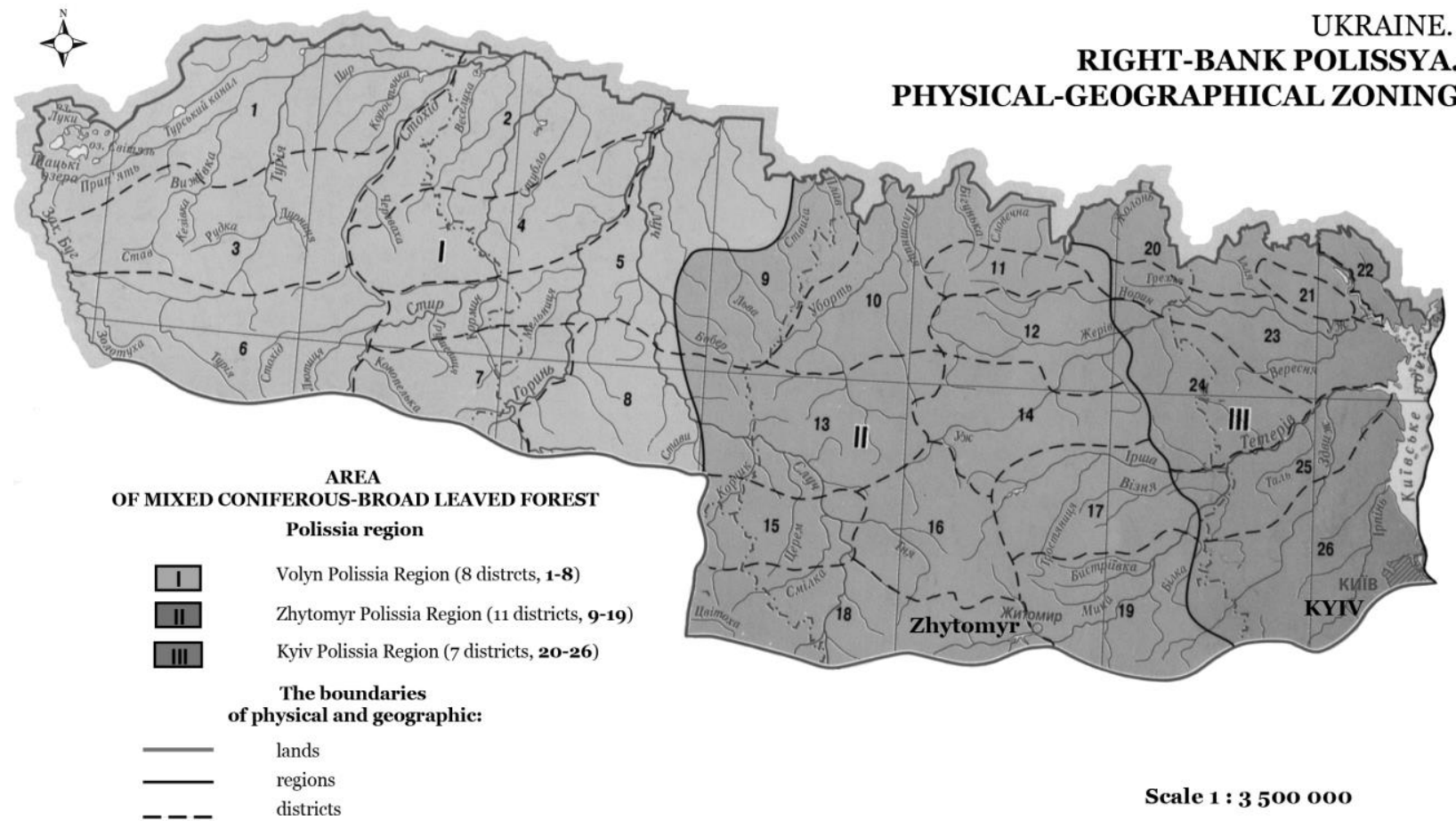

Figure 1. Physical-geographical zoning of Right-Bank Polissia. The scale value is given in the original (Source: Nesterchuk, 2011)

The soil cover of the Right-Bank Polissia is quite colorful (Figure 2). This is due to humid and mild climate, a large variety of chemical and granulometric composition of soil-forming rocks, well-developed meso- and microrelief with general flatness of the territory, close and very uneven occurrence of groundwater, diversity of flora and different in influence intensity of the human economic activity. The soilforming rocks have a predominantly light granulometric composition and are represented by sandy, clayey-sandy, sandy and loamy water- 
glacial, glacial and alluvial deposits. Occasionally, chalky-marl spots occur at the outcrops of massive crystalline rocks. In some places of the Right-Bank Polissia, small islets are covered with loessial deposits. One of the largest is the Slovechansk-Ovruch Ridge.

A large variety of soil-forming rocks, their granulometric and mineralogical composition, complex meso- and microrelief, are the cause of different conditions of moistening. Significant waterlogging, rich and varied vegetation cover have caused the formation of a very complicated soil cover in Polissia. The latter in most areas forms complexes and mosaics, characterized by small contours (average size of soil contours ranges from 20 to 50 ha). Sod-slightly podzolic and sod-medium podzolic soils predominate in Polissia. They occupy about $60 \%$ of the area of the zone. Due to the poor drainage of the area and the close groundwater, about $60 \%$ of the podzolic soils are silt and glue. The second largest area (about 20\%) is occupied by meadow and turf soils, which are distributed on the floodplain terraces of the rivers, in separate low-density declines on the overlying terraces and watersheds. Peatlands and peat-silt soils occupy the third place (10\%). They lie on the floodplain terraces of rivers and the bottoms of passage valleys, mostly lowland, rarely transitional types. A small area (1-1.5\%) is of sod-carbonate soils developed on Cretaceous rocks and nearly as much is occupied by gray and light gray podzolized soils, which are common in "loessial islands". Loessial soils are sedimentary rocks that occur in $74.8 \%$ of the territory of Ukraine (Arion, 2017). These are some of the best soils of the Polissia. In general, in the structure of the soil cover, $48.0 \%$ of the agricultural land of the zone is represented by sod-podzolic soils, $13.9 \%$ - light gray, gray forest, dark gray and partly black-soil podzolized, $14.6 \%$ - sod and silty soils, $6.0 \%$ peat bogs and peatlands. The composition of land is characterized by a significant proportion of arable land, which is $49.6 \%$. Turf carbonate soils are distributed in the south and southwestern part of Volyn Polissia based on products of weathered chalk marls and chalk. These soils have 3-6 to 8$12 \%$ humus. Gray forest soils occupy the largest areas on the Solvechansk-Ovruch Ridge, in the south of Zhytomyr Polissia (Polupan, 2005).

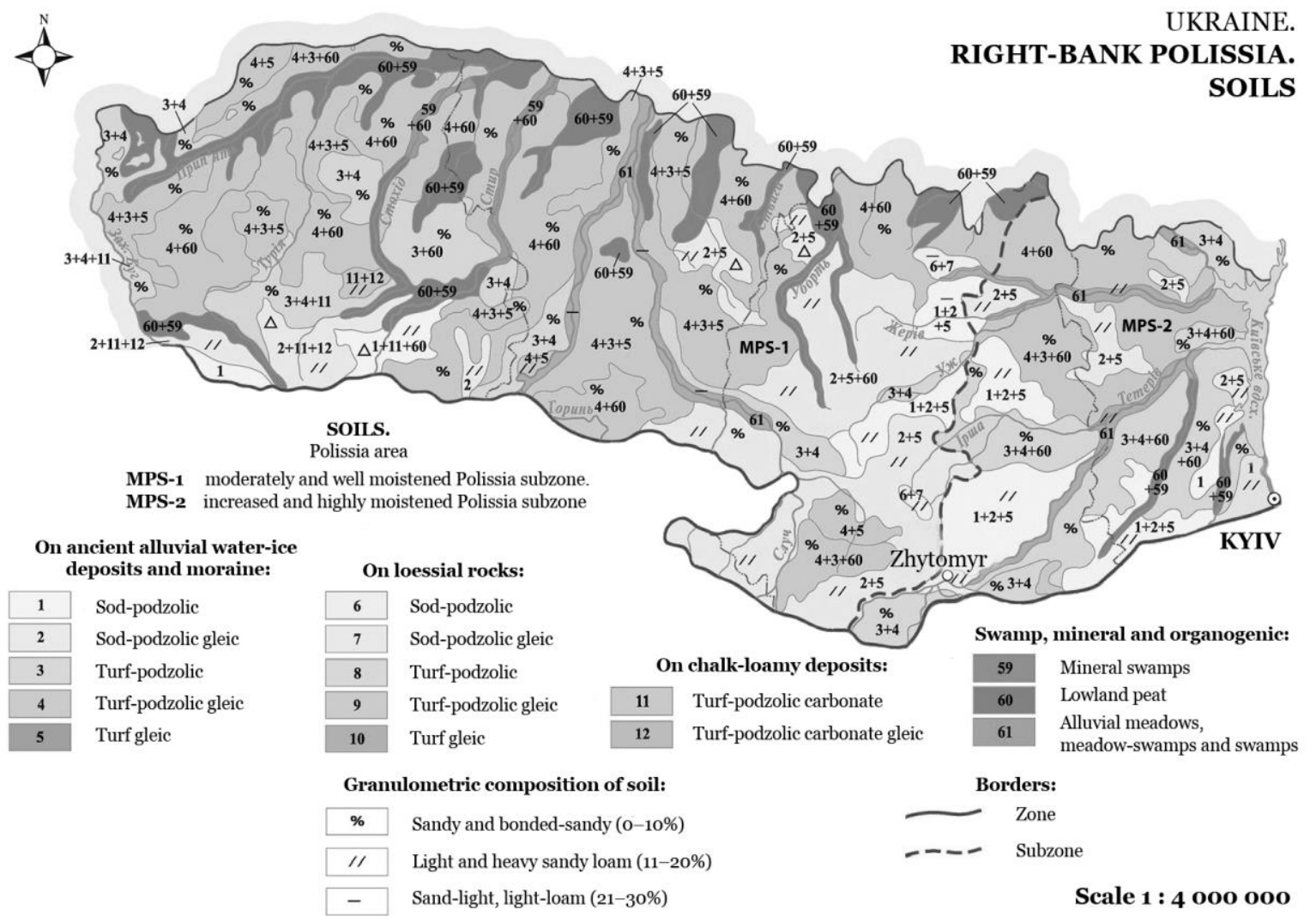

Figure 2. Soils of Right-Bank Polissia. The scale value is given in the original (Source: Polupan, 2005)

It is obvious that the natural conditions have also impact on traditional culture, food, architecture, clothing of Polishchuk-people, acting as an ethno-differentiating feature. Therefore, the ethnographic zoning of Ukraine, and in particular the Right-Bank Polissia, is based on local differences of traditional culture namely gastronomic. The ethnographic zoning of Ukraine is carried out comprehensively in terms of both material and spiritual, taking into account the following components (Makarchuk, 2012) (Figure 3).

The ethnographic zoning of Ukraine is based on the features of traditional dwellings, clothing, artistic crafts, food, occupations and tools, taking into account local peculiarities (Makarchuk, 2012) (Figure 4). Three regions Central-South-East, North or Polissia, SouthWest are studied as the empirical units. Our scientific research deals mainly with the Northern or Polissia region, namely its right-bank part (Right-Bank Polissia) which coincides with the natural strip of the Ukrainian Polissia and administratively covers the northern parts of Volyn, Rivne, Zhytomyr, Kyiv, Chernihiv and Sumy regions. The northern border of the region is the state border with Belarus and Russia, the southern boundary runs approximately through the cities of Volodymyr - Lutsk - Rivne - Korets - Novograd - Volyn Zhytomyr - Kyiv - Nizhyn - Borzna, further along the river Seim to the border with Russia. The Polissia region is divided into three subdistricts, due to socio-political conditions. Which have also imprinted on culture and life - East Polissia, Middle Polissia, West Polissia. We have studied West Polissia and Middle Polissia sub-regions (Makarchuk, 2012).

The heterogeneity of the Right-Bank Polissia in ethnographic terms is obvious, since the northern lands of the Volyn region do not constitute the entire Western Polissia, but are only part of it. Ethnographic zoning is based on the genetically related features of subethnicities and ethnographic groups, in particular Polishchuk-people, whose formation is influenced by geographical, historical, political, socio-economic, cultural factors. The endogenous and exogenous influence of these factors on the food traditions of the studied region is indisputable. Considering that the population of Right-Bank Polissia lived in the area of mixed forests, hunting, fishing and harvesting of wild plants such as viburnum, raspberries, blackberries, as well as mushrooms and honey of wild bees (beekeeping) prevailed in the 
economic activity of local residents. These products were the main diet of the local population in ancient times. Agriculture takes a secondary place because of the lack of forest-free land for horticulture and crop production, and secondly, common then millet or garden supplies (turnips, onions, peas, poppies) are easier to obtain as a result of product exchange.

\begin{tabular}{|c|c|}
\hline \multicolumn{2}{|c|}{$\begin{array}{l}\text { The components of culture that are taken into account } \\
\text { in the process of ethnographic zoning }\end{array}$} \\
\hline The spiritual realm & The material sphere \\
\hline $\begin{array}{l}\text { dialects and subdialects of the language; } \\
\text { ethics of family life; } \\
\text { traditions of public life; } \\
\text { the level of family life dependence on public } \\
\text { opinion; } \\
\text { calendar ceremonies; } \\
\text { peculiarities of family rituals; } \\
\text { oral tradition and folklore, literary and } \\
\text { artistic sources; } \\
\text { moral education through the prism of the } \\
\text { community; } \\
\text { food bans, fasting, suggestion } \\
\text { and other gastronomic traditions }\end{array}$ & $\begin{array}{l}\text { features of the cultivated areas: } \\
\text { land-use traditions; methods of tillage; } \\
\text { prevailing crops; the role of beekeeping, } \\
\text { fishing, hunting; tools of labor; methods of } \\
\text { storage, processing and use of agricultural } \\
\text { labor; ways and means of storage of raw } \\
\text { materials of different origin for gastronomy } \\
\text { in local centers (villages, farms) of } \\
\text { Right-Bank Polissia; traditional seeding and } \\
\text { gathering of food, subordinated to church } \\
\text { and ritual traditions, demonology; } \\
\text { types of settlements by social content: } \\
\text { villages, towns, columns, settlements, castles, } \\
\text { configuration and planning of yards; } \\
\text { types of yards: } \\
\text { free construction of buildings in the yard, } \\
\text { joining the buildings of the yard under a } \\
\text { common roof in one line, closed yards; } \\
\text { types of dwellings (houses): } \\
\text { by construction technique; features of the } \\
\text { exterior; } \\
\text { ensembles of folk women's and men's suits } \\
\text { and their components: } \\
\text { shoulder and waist, lower and outer } \\
\text { garments, types of hats and shoes; } \\
\text { food features: } \\
\text { types of traditional and ritual dishes, folk } \\
\text { etiquette, gastronomic local traditions in } \\
\text { methods and means of cooking; } \\
\text { dissemination of folk crafts } \\
\text { (artistic features of goods: types of ceramics, } \\
\text { embroidery, carpets, towels }\end{array}$ \\
\hline
\end{tabular}

Figure 3. The components of culture used in the ethnographic zoning of Ukraine (Source: Makarchuk, 2012, improved by the authors)

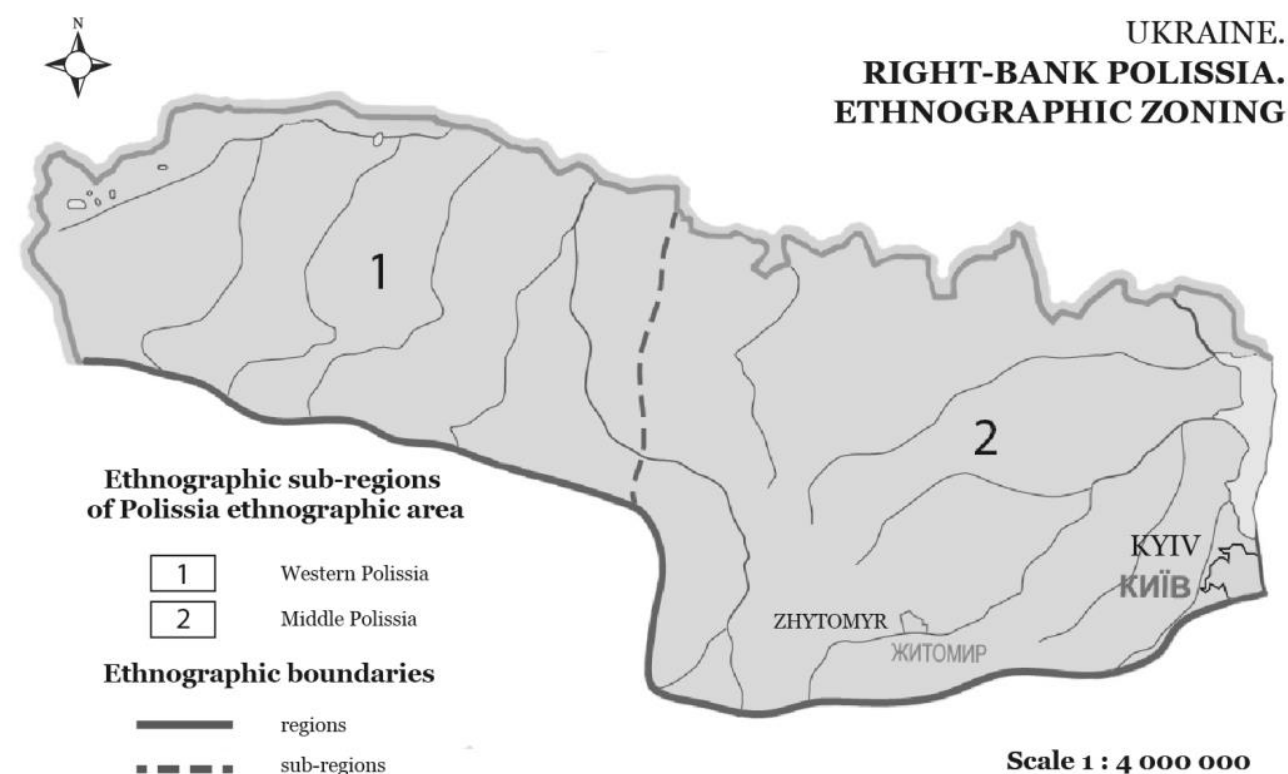

Figure 4. Ethnographic zoning of Right-Bank Polissia. The scale value is given in the original (Source: developed on the basis of Makarchuk, 2012) 
The Right-Bank Polissia has considerable opportunities for development of agriculture and stockbreeding. The soil and climatic conditions of the zone are favorable for the cultivation of cereals, legumes, spinning, root crops, potatoes, vegetables, perennials and annuals, as well as various berries and fruit crops. Rye was and still is the traditionally popular crop of the region. On the Ukrainian lands crop rye has been recorded since the $6^{\text {th }}$ century B.C. During the late $19^{\text {th }}$ - early $20^{\text {th }}$ century it occupied $50-60 \%$ of the sown area of Polissia. There were also buckwheat and millet, barley and oats. Wheat was poorly distributed because of unstable fertility on sandy or marshy soils. This ratio of grain crops remains virtually unchanged to this day. Peas and beans have also been grown since ancient times. Subsequently (in the $17^{\text {th }}$ century) beans appeared and spread rapidly. Potato, which gradually conquered Europe after the discovery of America, was especially widespread on the territory of Polissia and Ukraine in $18^{\text {th }}$ century. Vegetable crops in the region were widely represented by cabbage, cucumbers, beets, carrots, parsnips, celery, pumpkin, onions and garlic. Many people consumed horseradish and wild horseradish and sorrel.

Flax traditionally dominated among oilseeds, while hemp was sown in the rest of the territory. Moreover, redhead, rapeseed, mustard were grown. During the late $19^{\text {th }}$ century sunflower was gaining popularity. Gardening was less developed in the region than in the south of Ukraine. However, near apple, pear, plum, cherry, and berry bushes such as currant, raspberry, and viburnum grew the houses. Wild bushes of viburnum, blackberries, and elderberries were also widespread. Nowadays gardens are everywhere in Polissia. Berries and fruits are consumed fresh and dried. Most of the Ukrainian population was engaged in farming in the period of the second half of $13^{\text {th }}-$ early $17^{\text {th }}$ centuries. Part of the arable land was sown with rye and wheat, with much less acreage. Other cereals were barley, oats, peas, buckwheat, millet; among industrial crops - hemp, flax; garden-melons - turnips, onions, garlic, cabbage, pumpkins, beets, watermelons, melons, carrots, cucumbers, radish, beans, poppy seeds, lentils; garden - apples, pears, cherries, plums and bird-cherries. Among vegetable crops the following vegetables were used: cabbage (fresh and pickled), beets, radish, carrots, cucumbers, pumpkins. Local spicy-flavoring plants such as horseradish, onion, garlic, dill, crushed stone, cumin, anise, mint, tormentil, and also imported from other countries - pepper and cinnamon (cinnamon) were used as seasoning and flavoring. The formation of gastronomic culture took place within the small population during the period of the establishment of Kyiv state, when the tribes called Drevliany, Duliby, at the same time have gained the experience of the treatment and cooking the products of hunting and fishing or gathered wild plants fruit. The competitive nature of the flora and fauna of the physical-geographical regions of the Right-Bank Polissia, as well as the way of life-style of the local population, caused the similarity of gastronomic preferences, which found their expression in their most common dishes (Figure 5).

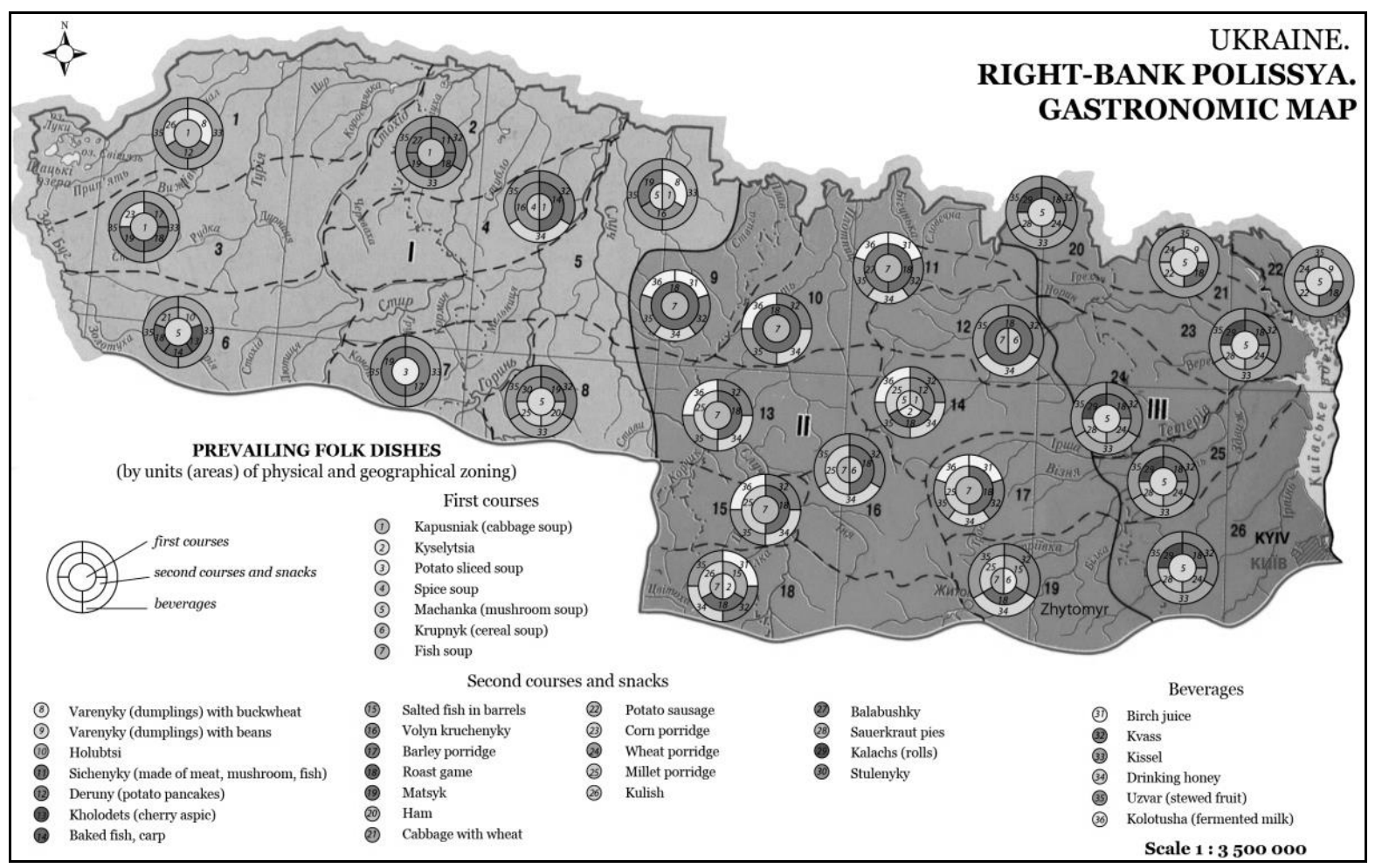

Figure 5. Gastronomic map of the Right-Bank Polissia. The scale value is given in the original (Source: authors' own research)

The cartographic model is created on the basis of elaboration of analytical works of topographic and statistical content, as well as fiction that are accumulative and based on factual material necessary for its generalization about gastronomy of the region. The information base for mapping has been developed by units of physical and geographical zoning. The whole gastronomy of the Right-Bank Polissia forms in stages and, despite the typical social obstacles in the processes of its own institutionalization, has retained its uniqueness to this day. Certainly, cooking cannot exist separately from the original identity of a national chef who has his or her own outlook, lifestyle, and characteristic details of everyday life that influence the cooking process (at the conscious and subconscious level). Therefore, "gastronomic tourism" is a sublimation of social values, in particular gastronomy, tourism, which form images of public memory for posterity and express not only verbal information about human activity, lifestyle, culture of food and recreation, but also capable of generating meaning, symbols and tastes. The further research is rather significant, as studies of the gastronomic potential of individual regions of Ukraine are unfortunately not fully studied in scientific publications. Tourism business frontiers are still being researched (Hall and Mitchell, 2006).

"Gastronomic potential" is a symbiosis of the resource (tourist and recreational), reserve (use and practical embodiment of inherent abilities: culinary, hotel-restaurant, institutional), opportunities (formation of new skills: culinary schools, master classes, blogs, tours, educational new model of leisure mass media), tourist infrastructure, manufacturer of gastronomic tourism product, institutions, attractions for the organization and implementation of tourist, recreational, gastronomic, hotel and restaurant, logistic, promotion activities in the region to meet human needs (Nesterchuk, 2018). At present, gastronomic destination is considered as a strategic object of entrepreneurship by 
individual investors at the regional level, although it is desirable to develop a strategy based on international investments . "Gastronomic destination" is a matrix that is based on the criteria of motivated subjects' involvement (based on "bottom-up initiatives"), clustering potential (public-private partnerships, cooperatives), competency-building and sustainable tourism development potential.

The guaranty to the sustainable functioning of individual tourism businesses in the united territorial communities in the future is to participate in the formation of a gastronomic tourist product of the gastronomic destination.

"Gastronomic tourist product" is a package of tangible and intangible elements (impressions, services, attractions, tourist resources) that can be purchased within the same travel destination.

Mass media, the instagram destination that provides information on its cultural features, attractions and gastronomic events, and in general about all tourist activities, including restaurants, hotels, culinary master classes, gastronomic festivals, chef gala - dinners, always attracts more tourists.

Our authorial vision - "gastronomic tourist" to be a tourist who travels for a well-defined gastronomic purpose, regardless of financial status, visiting both high-end establishments and catering establishments, or street food or autochthonous, traditional cuisine.

\section{CONCLUSIONS AND PROSPECTS OF THE STUDY}

The gastronomic space is typologized with reference to the dominant food culture of the individual region and historical period. This makes it possible to determine the characteristic conditions for the distribution and consumption of authentic dishes of the Right-Bank Polissia. As a result, in accordance with the purpose of our work, the characteristic features of the physical, geographical, soil and ethnographic zoning of Ukraine in the context of gastronomic culture are identified, which are to specify its definition, symptomatic circumstances of the origin of autochthonous dishes, the most important stages of its historical development and mutual interaction and the processes of organizing social life. Analysis of such features is made through the isolation in the field studies of the physical, geographical, soil and ethnographic epistemological properties of gastronomic culture, which became the prerequisites for the formation of a surprisingly heuristic concept for the diagnosis of gastronomic tourism in society and its further study. The gastronomic map of the Right-Bank Polissia is presented as an authentic food region that represents delicious, high-quality local cuisine whose dishes meet strict environmental standards. Since there is almost no professional literature and scientific articles on this subject, we have tried to introduce into the scientific terminology a number of definitions: "gastronomic tourism", "gastronomic potential", "gastronomic destination", "gastronomic tourist", "gastronomic tourist product". Thus, the search of new ways of nutrition organizing is based on the study of gastronomic tourism, gastronomic tourism product, on the basic principles of branding of the territory, in particular the Right-Bank Polissia, which shapes the tourist image of the area, in the process of creating a gastronomic impression in the tourists' minds. Local cuisine can be considered as a gastronomic tourist resource of the territory, which allows to produce new gastronomic tourist products, to open new facets of gastronomic tourist direction.

\section{Acknowledgments}

The authors are grateful to Doctor of Economics, Professor V. Tarasova for her thoughtful suggestions and comments. We also want to express words of gratitude to our colleagues at the department for the corrections and constructive comments they have made.

\section{REFERENCES}

Arion, O.V. (2017). Soil geography with the basics of soil science, Kyiv, $226 \mathrm{p}$.

Artiukh, L.F. (2018). Ukraine, state: food and food, Kyiv, 608 p.

Brokaj, M. (2014). The impact of the gastronomic offer in choosing tourism destination: The case of Albania. Academic Journal of Interdisciplinary Studies, $3(2), 249-249$.

Dasilva-Glasgow, D. (2015). Assessing the Economic Potential for Culinary Tourism in Suriname: a Value Chain Approach. St. Augustine, 59 p

Gheorghe, G., Tudorache, P., \& Nistoreanu, P. (2014). Gastronomic tourism, a new trend for contemporary tourism. Cactus Tourism Journal, 9(1), 12-21.

Glushko, M. (2009). Ethnographic zoning of Ukraine: current state, problems, tasks (according to research materials the end of 19 th - beginning of $20^{\text {th }}$ centuries), Lviv, pp. 179-214.

Hall, C.M., \& Mitchell, R. (2006). Tourism Business Frontiers: Consumers, Products and Industry, Amsterdam: Elsevier Butterworth-Heinemann, pp. $137-147$.

Kirchiv, R. (2005). Pre-scientific interest in Ukrainian folklore and ethnography, Kyiv, p. 52-65.

LeHeup, R. (2015). Ontario Culinary Tourism Alliance, Skift Present: the Rise of Food Tourism, 29 p.

Lyubitseva, O.O. (2002). The market of tourist services (geospatial aspects), Kiev, $436 \mathrm{p}$.

Makarchuk, S.A. (2012). Historical and ethnographic works of Ukraine, Lviv, 352 p.

Marynych, O.M. (2005). Physical Geography of Ukraine, Kyiv, 512 p.

Matlovičová, K., \& Pompura, M. (2013). The Culinary Tourism in Slovakia Case Study of the Traditional Local Sheep's Milk Products in the regions of Orava and Liptov. GeoJournal of Tourism and Geosites, 2(12), 129-144.

Nesterchuk, I.K. (2011). Geo-ecological analysis: conceptual approach, sustainable development, Zhytomyr, 312 p.

Nesterchuk, I.K. (2018). Imprints of the food of Polissya people on the body of the physical and geographical area of Volyn Polissya, Kherson, Vyp. 7, pp. $210-214$

Oliynyk, Y.B., Shishchenko, P.G., Stepanenko, A.V. \& Maslyak, P.A. (2008). Geography: Ukraine and the world, Kyiv, 456 p.

Pankiv, M.I. (2005). Organization of Field Studies in Ethnography, Ivano-Frankivsk, 128 p.

Polupan, M.I. (2005). Soil classification of Ukraine, Kyiv, 300 p

Ponomaryov, A. (1994). Ukrainian Ethnography, Kyiv, 316 p.

Pullphothong, L., \& Sopha, C. (2013). Gastronomic Tourism in Ayutthaya, Thailand. In Proceedings of the International Conference on Tourism, Transport, and Logistics (Vol. 1416).

Rogerson, C.M., \& Rogerson, J.M. (2019). Tourism, local economic development and inclusion: evidence from Overstrand Local Municipality, South Africa. GeoJournal of Tourism and Geosites, 25(2), 293-308. https://doi.org/10.30892/gtg.25202-360.

Savchuk, B. (2004). Ukrainian Ethnology, Ivano-Frankivsk, 559 p.

Tereshina, T.V., \& Vasilenko, V.I. (2012). Soils of the USSR, Moscow, 360 p.

Tivodar, M. (2010). Ethnology, Uzhgorod, 504 p.

Yurtseven, H.R. (2011). Sustainable gastronomic tourism in Gokceada (Imbros): Local and authentic perspectives. International Journal of Humanities and Social Science, 1(18), 17-26. 